\title{
AKTIVITAS ANTIHIPERURISEMIA BEBERAPA EKSTRAK DAUN MANGGA (Mangifera indica L) VAR. CENGKIR TERHADAP TIKUS PUTIH JANTAN GALUR WISTAR YANG DIINDUKSI KALIUM OKSONAT
}

\author{
Ghina Nadhifah, Nur Laili Dwi Hidayati, Hendy Suhendy* \\ Program Studi S1 Farmasi, STIKes Bakti Tunas Husada ${ }^{1}$ \\ *Email: radhwa04@gmail.com
}

Received: 07/07/2021, Revised: 29/07/2021, Accepted: 04/08/2021, Published: 18/08/2021

\begin{abstract}
ABSTRAK
Daun mangga (Mangifera indica L) secara empiris telah digunakan oleh masyarakat untuk mengobati penyakit. Secara ilmiah infusa tanaman ini efektif dalam menurunkan asam urat. Penelitian ini telah dilakukan untuk menguji aktivitas antihiperurisemia beberapa ekstrak daun mangga (Mangifera indica L) varietas cengkir berdasarkan perbedaan polaritasnya pada tikus putih jantan galur Wistar. Maserasi bertingkat dengan pelarut n-heksana, etil asetat dan etanol $70 \%$ digunakan sebagai metode ekstraksi. Dosis ekstrak n-heksana yang digunakan adalah 15 $\mathrm{mg} / 200 \mathrm{~g} \mathrm{BB}$ tikus, sedangkan dosis ekstrak etil asetat dan ekstrak etanol $70 \%$ adalah $20 \mathrm{mg} / 200$ g BB tikus serta allopurinol sebagai obat standar adalah $1,8 \mathrm{mg} / 200 \mathrm{~g}$ BB tikus. Pengujian ini dilakukan pada tikus hiperurisemia yang diinduksi kalium oksonat dengan dosis $50 \mathrm{mg} / 200 \mathrm{~g} \mathrm{BB}$ tikus secara intraperitoneal dan jus hati ayam secara oral. Pengukuran kadar asam urat darah dilakukan dengan menggunakan Easy Touch ${ }^{\circledR}$. Hasil pengujian menunjukkan penurunan kadar asam urat pada ekstrak etanol, ekstrak etil asetat dan n-heksana berturut-turut sebesar 50,61\%,; $49,84 \%$ dan $42,17 \%$. Tidak terdapat perbedaan bermakna data kadar asam urat antara kelompok kontrol positif, kelompok dosis ekstrak etanol dan kelompok dosis etil asetat. Kelompok dosis ekstrak etanol dan ekstrak etil asetat memberikan aktivitas antihiperurisemia terbaik. Perlu pengujian parameter lain untuk memastikan aktivitas antihiperurisemia beberapa ekstrak daun manga varietas cengkir.
\end{abstract}

Kata kunci : Antihiperurisemia, Daun Mangga (Mangifera indica L) Varietas Cengkir, Ekstrak, Kalium Oksonat, Jus Hati Ayam

\section{ABSTRACT}

Mango leaves (Mangifera indica L) empirically have been used by the people to treat the deseases. This plant infusion Scientifically effective to reduce the uric acid. The study was conducted to determine the antihyperuricemic activity of several cengkir variety mango leaf extracts (Mangifera indica L) based on their polarity differences in male white rats of the Wistar strain. Multilevel maceration with n-hexane, ethyl acetate and $70 \%$ ethanol solvent was used as the extraction method. The dose of n-hexane extract used was $15 \mathrm{mg} / 200 \mathrm{~g} \mathrm{BW}$ of rats, while the dose of ethyl acetate extract and $70 \%$ ethanol extract was $20 \mathrm{mg} / 200 \mathrm{~g} \mathrm{BW}$ of rats and allopurinol as standard drug was $1.8 \mathrm{mg} / 200 \mathrm{~g}$ BW of rats. This test was carried out on hyperuricemic rats induced by potassium oxonate with a dose of $50 \mathrm{mg} / 200 \mathrm{~g} \mathrm{BW}$ rats intraperitoneally and chicken 
liver juice orally. Easy Touch ${ }^{\circledR}$ was used as measurement of blood uric acid levels method. The result showed that the decreases of uric acid levels in the ethanol extract, ethyl acetate and nhexane extract respectively were 50.61\%, 49.84\% and $42.17 \%$. There was no significant difference in uric acid level data between the positive control group, the ethanol extract dose group and the ethyl acetate dose group. The dose group of ethanol extract and ethyl acetate extract gave the best antihuperuricemic activity. Need to test other parameters to make sure antihyperuricemic activity of the several cengkir variety mango leaves extracts.

Keywords: Antihyperuricemia, Cengkir Variety Mango Leaf (Mangifera indica L), Extract, Potassium Oxonate, chicken liver juice

\section{PENDAHULUAN}

Hiperurisemia terjadi ketika ada peningkatan kadar asam urat. Keadaan dimana ginjal gagal mengeksresikan asam urat sehingga mengakibatkan tingginya kadar asam urat disebabkan karena peningkatan jumlah asam urat yang terjadi didalam darah hingga melewati batas normal (Hidayah, Hasanah, \& Gunawan, 2018). Dikatakan hiperurisemia apabila konsentrasi serum asam urat dalam darah untuk pria > $7 \mathrm{mg} / \mathrm{dL}$ dan untuk wanita > $6 \mathrm{mg} / \mathrm{dL}$ (Ardiyanti, 2018). Kadar asam urat dapat dipengaruhi oleh jenis makanan yang mengandung purin tinggi, seperti jeroan (hati, ginjal, dan paru), bayam termasuk jenis makanan yang paling digemari oleh masyarakat Indonesia (Wahyuningsih, Yulinah, Sukrasno, \& Karina, 2015).

Pengobatan hiperurisemia umumnya menggunakan allopurinol. Obat tersebut bekerja dengan cara menghambat aktivitas xantin oksidase. Enzim xantin oksidase akan mengubah hipoxantin menjadi xantin dan selanjutnya diubah menjadi asam urat 176
(Departemen Farmakologi dan Terapeutik, 2016).

Secara empiris salah satu tanaman yang berpotensi sebagai tanaman obat adalah tanaman mangga. Masyarakat Kec. Manonjaya Kab. Tasikmayala Prov. Jawa Barat menggunakan daun mangga (Mangifera indica L.) untuk pengobatan antihiperurisemia dan dibuktikan dalam penelitian dengan hasil yang menunjukkan bahwa infusa daun manga varietas cengkir (Mangifera indica L.) dengan dosis 162 $\mathrm{mg} / 200 \mathrm{~g}$ BB tikus yang diinduksi oleh kalium oksonat efektif untuk menurunkan asam urat (Afifah, 2018).

Perbedaan polaritas pelarut ekstraksi mempengaruhi senyawa golongan metabolit sekunder dan aktivitas farmakologisnya (Fidrianny, Suhendy, \& Insanu, 2018). Oleh sebab itu penelitian ini bertujuan untuk membandingkan dan menentukan aktivitas antihiperurisemia terbaik dari beberapa ekstrak daun mangga (Mangifera indica L) berdasarkan perbedaan polaritasnya. 


\section{METODE PENELITIAN}

\section{Alat dan Bahan}

Alat pengering simplisia, blender (Philips), maserator, vacum rotary evaporator (IKA)®, oven (Memmert)®, tanur (Thermo scientific) ${ }^{\circledR}$, Shake Waterbath (Memmert@), desikator, kandang pemeliharaan hewan, syring, sonde oral, Easy Touch ${ }^{\circledR}$ GCU dengan Uric Acid Test Strip dan alat-alat lain yang lazim digunakan di Laboratorium.

Simplisia daun mangga (Mangifera indica L.) varietas cengkir, Etanol (Germany,Merck), n-Heksana (Germany,Merck), Etil Asetat (Germany,Merck), Chloral Hydrate (Germany,Merck), asam klorida, asam sulfat, serbuk magnesium, amil alkohol, anhidrida asetat, asam nitrat pekat, kloroform, reagen mayer, reagen Lieberman burchard, reagen dragendorf, CMC (Carboxymethylcellulose), pakan tikus, Allopurinol (Sigma-Aldrich), Potasium oxonate (Sigma-Aldrich), jus hati ayam dan aquadest.

Hewan yang digunakan adalah tikus putih jantan galur Wistar yang berumur 3-4 bulan dengan berat badan 200-220 gram sebanyak 24 ekor tikus. Hewan uji diperoleh dari Alluna Mouse Farm, Kab. Ciamis, Jawa Barat.

\section{Jalannya Penelitian}

1. Pengumpulan, Determinasi dan Pengolahan Bahan Tanaman

Bahan berupa daun mangga (Mangifera indica L.) varietas cengkir diperoleh dari kebun warga masyarakat daerah Paseh, Kecamatan Cihideung Kota Tasikmalaya kemudian dilakukan determinasi di SITH, FMIPA, Institut Teknologi Bandung.

Pengolahan simplisia diawali dengan pengambilan simplisia segar, pencucian, sortasi basah, pengeringan, sortasi kering, penggilingan hingga penyimpanan serbuk kering simplisia daun mangga (Mangifera indica L.)

2. Karakterisasi Simplisia

Karakterisasi meliputi pemeriksaan makroskopik, pemeriksaan mikroskopik dan penapisan fitokimia simplisia.

Pemeriksaaan makroskopik meliputi karakteristik bentuk, warna, rasa dan bau serbuk simplisia. Pemeriksaan ini dilakukan dengan meletakkan serbuk simplisia di atas kaca objek dan memberi beberapa tetes air, kemudian diamati di bawah mikroskop.

Penapisan fitokimia simplisia dilakukan terhadap metabolit sekunder golongan flavonoid, alkaloid, tanin, polifenol, saponin, steroid, terpenoid, monoterpenoid dan triterpenoid sesuai 
prosedur pada panduan yang tercantum pada jurnal Farnsworth (1966).

\section{Ekstraksi}

Simplisia daun mangga (Mangifera indica L.) sebanyak 450 gram diekstraksi dengan metode maserasi bertingkat menggunakan tiga jenis pelarut yaitu nheksan, etil asetat dan etanol $70 \%$ secara berurutan masing-masing selama 3x24 jam dan setiap 24 jam dilakukan pergantian pelarut. Ekstrak cair hasil maserasi dikumpulkan kemudian diuapkan dengan Rotary Evaporator hingga diperoleh ekstrak kental. Ekstrak kemudian ditimbang dan diperoleh bobot ekstrak kental kemudian dihitung rendemen masing-masing ekstrak.

4. Karakterisasi Ekstrak

Karakterisasi yang dilakukan hanya penapisan fitokimia terhadap metabolit sekunder golongan flavonoid, alkaloid, tanin, polifenol, saponin, steroid, terpenoid, monoterpenoid dan triterpenoid dengan cara yang sama seperti pada penapisan fitokimia simplisia.

5. Pengujian Aktivitas Penurunan Kadar Asam Urat

Hewan uji sebanyak 24 ekor tikus dibagi menjadi 6 kelompok yang masingmasing kelompok terdiri dari 4 ekor. Sebelum pengujian dimulai tikus diadaptasikan terlebih dahulu selama 7 hari, dengan tetap diberi makan dan minum.

Perlakuan dilakukan selama 14 hari karena berdasarkan pada penelitian Putra, Azizah, \& Clara (2019). Hewan uji dibuat hiperurisemia dengan memberikan jus hati ayam secara oral dan kalium oksonat dosis 50 $\mathrm{mg} / 200 \mathrm{~g}$ BB tikus secara intraperitonial kecuali pada kelompok normal. Pemberian kalium oksonat diberikan pada hari ke 7 secara intraperitonial setelah pemberian jus hati ayam selama 7 hari berturut-turut. Kemudian dilakukan pemeriksaan asam urat 1 jam setelah pemberian kalium oksonat. Pengambilan sampel darah melalui vena lateral ekor kemudian darah di teteskan pada Easy Touch ${ }^{\circledR}$ GCU tes strip. Setelah pemeriksaan kadar asam urat, diberi perlakuan sebagai berikut:

a. Kelompok kontrol normal (tidak diberi perlakuan).

b. Kelompok kontrol positif (Allopurinol dosis dosis 1,8 mg/200 g BB tikus secara oral).

c. Kelompok kontrol negatif (Larutan suspensi CMC 1\% secara oral)

d. Kelompok ekstrak n-heksana daun mangga dosis $15 \mathrm{mg} / 200 \mathrm{~g} \mathrm{BB}$ secara oral). 
e. Kelompok ekstrak etil asetat daun mangga dosis $20 \mathrm{mg} / 200 \mathrm{~g}$ BB tikus secara oral).

f. Kelompok ekstrak etanol $70 \%$ daun mangga dosis $20 \mathrm{mg} / 200 \mathrm{~g}$ BB tikus secara oral).

Selanjutnya setelah pemberian sediaan pada hari ke 8 sampai hari ke 14 kemudian dilakukan pengukuran kadar asam urat terapi tikus. Untuk kelompok normal (tidak diberi perlakuan), pengambilan darah langsung dilakukan setelah tikus dipuasakan selama 18 jam. Setelah diperoleh data kadar asam urat kemudian dilakukan perhitungan efektivitas penurunan kadar asam urat dengan rumus sebagai berikut :

$\%$ Penurunan $=\frac{\text { Rata }- \text { rata Kontrol Negatif }- \text { Rata }- \text { rata Kel Uji }}{\text { Rata-rata Kontrol Negatif }}$

\section{Analisis Data}

Data kadar asam urat dianalisis secara statistik menggunakan One Way ANOVA dan post hoc test LSD dengan software SPSS ver. 16.00 untuk melihat apakah data uji antihiperurisemia pada masing-masing kelompok memiliki perbedaan yang signifikan atau tidak $(\mathrm{p}<0,05)$.

Efektivitas penurunan kadar asam urat dihitung dengan rumus :

$\%$ Penurunan $=\frac{\text { Rata-rata Kontrol Negatif-Rata-rata Kel Uji }}{\text { Rata-rata Kontrol Negatif }}$

\section{HASIL DAN PEMBAHASAN}

1. Penyiapan Bahan Uji dan Determinasi Tanaman

Hasil determinasi sesuai surat No. 2I16/E-SP/SITKes/XI/2019 menunjukkan tanaman yang digunakan adalah daun mangga (Mangifera indica L.) varietas cengkir. Setelah dilakukan pengolahan bahan diperoleh rendemen serbuk simplisia kering sebesar $22,5 \%$.

\section{Karakterisasi Simplisia}

Karakterisasi organoleptik simplisia yang dilakukan meliputi pemeriksaan makroskopik dan mikroskopik serbuk simplisia dan dibandingkan dengan parameter standarnya (Rakholiya \& Chanda, 2012). Hasil pengamatan menunjukkan bahwa sampel yang digunakan adalah daun manga varietas cengkir seperti yang terlihat pada Tabel 1 .

Tabel 1. Hasil pengujian makroskopik dan mikroskopik simplisia daun manga varietas cengkir

\begin{tabular}{lcccc}
\hline Simplsia & Rasa & Warna & Bau & $\begin{array}{c}\text { Fragmen } \\
\text { spesifik }\end{array}$ \\
\hline Daun & pahit & Hijau & $\begin{array}{c}\text { Stomata, } \\
\text { kristal } \\
\text { berbau }\end{array}$ & $\begin{array}{c}\text { prisma, } \\
\text { rambut } \\
\text { penutup, } \\
\text { mangga }\end{array}$ \\
& & & & $\begin{array}{c}\text { sel } \\
\text { epidermis }\end{array}$ \\
\hline
\end{tabular}

Penapisan fitokimia dilakukan terhadap simplisia untuk mengetahui keberadaan metabolit sekunder. Hasil 
penapisan fitokimia simplisia pada Tabel 2 terlihat bahwa kedua simplisia mengandung senyawa golongan flavonoid dan fenol dimana golongan tersebut merupakan kontributor utama aktivitas antioksidan.

Tabel 2. Penapisan fitokimia simplisia daun mangga varietas cengkir

\begin{tabular}{lc}
\hline \multicolumn{1}{c}{ Golongan senyawa } & Simplisia \\
\hline Alkaloid & - \\
Flavonoid & + \\
Saponin & + \\
Tanin/polifenol & + \\
Steroid/triterpenoid & + \\
Kuinon & + \\
Seskuiterpen/monoterpen & - \\
\hline Keterangan: + = terdeteksi & \\
\multicolumn{1}{r}{ - = tidak terdeteksi } &
\end{tabular}

3. Ekstraksi

Ekstraksi dilakukan dengan metode maserasi bertingkat menggunakan tiga jenis pelarut berbeda kepolaran untuk menghasilkan senyawa tertentu yang terekstrak secara spesifik pada tiap pelarut yang digunakan (Permadi, Sutanto, \& Wardatun, 2015). Hasil ekstraksi dikonversi ke dalam persentase rendemen yang dapat dilihat dapat dilihat pada Tabel 3.

Tabel 3. Rendemen bebrapa ekstrak daun manga varietas cengkir

\begin{tabular}{cc}
\hline Sampel Ekstrak & Rendemen (\%) \\
\hline n-Heksana & 1,71 \\
Etil asetat & 0,19 \\
Etanol 70\% & 12,3 \\
\hline
\end{tabular}

Berdasarkan rendemennya, pelarut yang paling efektif dalam menyari senyawa- senyawa metabolit sekunder adalah etanol $70 \%$ karena diduga mayoritas senyawasenyawa metabolit sekunder yang ada dalam simplisia daun manga bersifat polar sehingga akan lebih tertarik oleh pelarut ini. Hal ini sesuai dengan penelitian Noviyanty (2019) yang menyatakan bahwa rendemen ekstrak etanol lebih tinggi dibandingkan pelarut yang lainnya.

4. Karakterisasi Ekstrak

Tabel 4. Penapisan fitokimia beberapa ekstrak daun mangga varietas cengkir

\begin{tabular}{lccc}
\hline \multicolumn{1}{c}{ Golongan senyawa } & EHek & EEtas & EtOH \\
\hline Alkaloid & - & - & - \\
Flavonoid & + & + & + \\
Saponin & - & - & - \\
Tanin/polifenol & - & - & + \\
Steroid/triterpenoid & - & - & - \\
Kuinon & - & - & - \\
Seskuiterpen/monoterpen & - & - & - \\
\hline \multicolumn{2}{c}{ Keterangan: EHek = Ekstrak n-Heksana } \\
EEtas = Ekstrak etil asetat \\
EEtOH = Ekstrak etanol 70\% \\
$+=$ terdeteksi \\
- = tidak terdeteksi
\end{tabular}

Karakterisasi fitokimia dilakukan terhadap ekstrak untuk mengetahui ada atau tidaknya senyawa-senyawa golongan metabolit sekunder yang diujikan setelah melalui tahap ekstraksi. Hasil pengamatan pada Tabel 4 menunjukkan bahwa senyawa golongan flavonoid yang masih terdapat pada ketiga ekstrak sedangkan tannin/polifenol hanya terdapat pada ekstrak etanol. Secara kualitatif metode maserasi bertingkat hanya 
efektif untuk menyari senyawa golongan flavonoid.

5. Hasil Uji Aktivitas Penurunan Asam Urat

Hewan yang digunakan dalam penelitian ini yaitu tikus putih jantan galur wistar dikarenakan memiliki kemiripan dengan manusia dalam hal fisiologi, anatomi, patologi atau metabolisme (Umboh, Queljoe, \& Yamlean, 2019). Kemudian jenis kelamin jantan digunakan karena tikus jantan memiliki kestabilan hormonal dibanding tikus betina, tikus betina mengalami siklus estrus masa kehamilan dan menyusui yang akan mempengaruhi kondisi psikologis hewan uji. Tikus putih jantan (Rattus norvegicus) tidak memiliki hormon estrogen, walaupun ada jumlahnya sangat sedikit. Hormon estrogen bermanfaat untuk meningkatkan pengeluaran asam urat melalui urin (Rakanita, Hastuti, Tandi, \& Mulyani, 2017).

Keadaan hiperurisemia pada tikus jantan diperoleh dengan pemberian kalium oksonat dan jus hati ayam. Jus hati ayam digunakan sebagai penginduksi asam urat karena hati ayam merupakan makanan yang mengandung tinggi purin kemudian akan memacu terbentuknya asam urat oleh enzim xantin oksidase (Suwandi \& Perdana, 2018). Penginduksi lain yang digunakan adalah kalium oksonat yang berpotensi menghambat enzim uricase yang dapat mengurai asam urat menjadi allantoin yang dapat larut dalam air. Jika enzim tersebut dihambat maka akan terjadi penumpukan asam urat dalam tubuh hewan uji sehingga kadar asam urat darah meningkat. Keadaan hiperurisemia diperlukan untuk mengetahui apakah sediaan uji yang digunakan dapat menurunkan kadar asam urat atau tidak (Himawan, Effendi, \& Gunawan, 2017). Hasil pengujian asam urat dapat dilihat pada Tabel 5.

Tabel 5. Rata-rata Kadar Asam Urat Setelah Induksi dan Setelah Perlakuan

\begin{tabular}{lcc}
\hline \multirow{1}{*}{ Kelompok } & \multicolumn{2}{c}{$\begin{array}{c}\text { Kadar Asam Urat } \\
\text { (Rataan } \pm \text { SD) }\end{array}$} \\
\cline { 2 - 3 } & $\begin{array}{c}\text { Sebelum } \\
\text { Perlakuan }\end{array}$ & $\begin{array}{c}\text { Setelah } \\
\text { Perlakuan }\end{array}$ \\
\hline Kontrol Normal & $3,02 \pm 0,17$ & $3,2 \pm 0,29^{*}$ \\
Kontrol Negatif & $6,6 \pm 0,69$ & $6,52 \pm 0,58$ \\
Kontrol Positif & $5,92 \pm 0,41$ & $3,17 \pm 0,27^{*}$ \\
$\begin{array}{l}\text { Dosis Ekstrak } \\
\text { Etanol }\end{array}$ & $6,27 \pm 0,17$ & $3,22 \pm 0,25^{*}$ \\
$\begin{array}{l}\text { Dosis Ekstrak } \\
\text { Etil Asetat }\end{array}$ & $6,37 \pm 0,39$ & $3,27 \pm 0,17^{*}$ \\
$\begin{array}{l}\text { Dosis Ekstrak N- } \\
\text { heksan }\end{array}$ & $6,97 \pm 0,66$ & $3,77 \pm 0,60^{*}$ \\
\hline Keksan
\end{tabular}

Keterangan : * = Terdapat perbedaan yang signifikan $(\mathrm{p}<0,05)$ nilai asam urat dibandingkan dengan kontrol negatif setelah perlakuan

Pada tabel tersebut dapat diamati bahwa setelah pemberian hati ayam dan kalium oksonat terjadi peningkatan kadar asam urat darah hewan uji jika dibandingkan dengan kelompok normal. Hal ini menunjukkan bahwa induktor yang 
digunakan berhasil dalam menghambat enzim urikase sehingga menghambat pengubahan asam urat menjadi allantoin sehingga kadar asam urat darah meningkat.

Kadar asam urat tikus setelah perlakuan pada kelompok kontrol negatif termasuk kategori hiperurisemia. Hal tersebut menunjukan bahwa CMC tidak begitu berpengaruh dalam penurunan kadar asam urat tikus. Disisi lain kadar asam urat tikus kelompok kontrol positif dan ketiga kelompok dosis ekstrak menunjukan menunjukkan nilai yang termasuk kategori normal (1,2 - 5,0 mg/dL) (Rukmana, Choesrina, \& Fitrianginsih, 2017).

Hasil analisis statistik one way ANOVA menunjukkan bahwa pemberian perlakuan berpengaruh terhadap kadar asam urat karena nilai kadar asam urat kelompok kontrol positif dan ketiga kelompok dosis ekstrak berbeda signifikan $(\mathrm{p}<0,05)$ dibandingkan dengan kelompok kontrol negatif. Sedangkan berdasarkan uji post hoc LSD tidak ada perbedaan signifikan $(p<0,05)$ kadar asam urat kelompok kontrol positif dengan kelompok dosis ekstrak etil asetat dan kelompok dosis ekstrak etanol sehingga baik kelompok kontrol positif dan kedua kelompok dosis ekstrak ini memiliki aktivitas antihiperurisemia yang sama.
Tabel 6. Efektivitas Penurunan Kadar Asam Urat Kelompok Dosis Ekstrak nHeksana, Etil Asetat dan Etanol

\begin{tabular}{lc}
\hline \multicolumn{1}{c}{ Kelompok } & Efektivitas (\%) \\
\hline Dosis Ekstrak Etanol 70\% & 50,61 \\
Dosis Ekstrak Etil Asetat & 49,84 \\
Dosis Ekstrak N-heksan & 42,17 \\
\hline
\end{tabular}

Pada Tabel 6, dapat dilihat bahwa kelompok dosis ekstrak etanol memiliki persen penurunan kadar asam urat paling tinggi. Hal ini sejalan dengan data kadar asam urat pada Tabel 5 dimana kelompok dosis ekstrak etanol memiliki nilai yang paling kecil dibandingkan kelompok dosis ekstrak yang lain.

Kemampuan beberapa ekstrak daun mangga dalam menurunkan kadar asam urat darah tikus disebabkan oleh senyawa metabolit sekunder yang terdapat dalam ekstrak daun mangga tersebut. Senyawa golongan flavonoid atau polifenol diduga dapat menurunkan kadar asam urat. Struktur dari flavonoid menyebabkan senyawa ini berpotensi sebagai inhibitor kompetitif bagi xantin oksidase. Flavonoid merupakan golongan senyawa metabolit sekunder yang berperan sebagai antioksidan. Daya antioksidan dalam flavonoid dapat mencegah oksidasi xantin dan hipoxantin menjadi asam urat oleh xantin oksidase (Inhibisi terhadap xantin oksidase dapat menurunkan produksi 
asam urat dalam darah (Juwita, Saleh, \& Sitorus, 2017).

\section{KESIMPULAN}

Nilai penurunan kadar asam urat kelompok dosis ekstrak ekstrak etanol, etil asetat dan n-heksan berturut-turut adalah sebesar $50,61 \% ; 49,84 \%$ dan $42,17 \%$. Kelompok dosis ekstrak etanol dan ekstrak etil asetat memberikan aktivitas antihuperurisemia yang paling baik.

\section{DAFTAR PUSTAKA}

Afifah, M. (2018). Uji Aktivitas Antihiperurisemia Infusa Daun Mangga Pada Tikus Putih Jantan Diinduksi Kalium Oksonat. STIKes Bakti Tunas Husada Tasikmalaya.

Ardiyanti, R. (2018). Efek Antihiperurisemia Ekstrak Etanol Herba Pugun Tanoh (Picria fel-terrae Lour). Universitas Sumatera Utara, Medan.

Departemen Farmakologi dan Terapeutik

Fakultas Kedokteran Universitas Indonesia. (2016). Farmakologi dan Terapi. Jakarta : Balai Penerbit FK UI. Farnsworth, N. (1966). Biological and Phytochemical Screening of Plants. J.Pharm. Sci, 55(3), 225-276.

Fidrianny, I., Suhendy, H., \& Insanu, M. (2018). Correlation of phytochemical content with antioxidant potential of various sweet potato (Ipomoea batatas) in West Java, Indonesia. Asian Pacific Journal of Tropical Biomedicine, 8(1), 25.

Hidayah, N., Hasanah, F., \& Gunawan, M. (2018). Uji efektivitas Antihiperurisemia Ekstrak Air Daun Salam (Syzygium polyanthum Wight.) terhadap Mencit Jantan (Mus musculus) yang Diinsuksi Jus Hati Ayam dan Kalium Oksonat. Jurnal Penelitian Saintika, 18(1), 24-31.

Himawan, H., Effendi, F., \& Gunawan, W. (2017). Efek Pemberian Ekstrak Etanol 70\% Tanaman Suruhan (Peperomia pellucida (I). H.b.k) terhadap Kadar Asam Urat Darah Tikus Spragua Dawley yang Diinduksi Kalium Oksonat. Fitofarmaka: Jurnal Ilmiah Farmasi, 7(2), 7-14.

Juwita, R., Saleh, C., \& Sitorus, S. (2017). Uji aktivitas antihiperurisemia dari daun hijau tanaman pucuk merah (Syzygium myrtifolium walp.) terhadap mencit jantan (Mus musculus). Jurnal Atomik, 2(1), 86-92.

Noviyanty, A., Salingkat, A., \& Syamsiar. (2019). Pengaruh Jenis Pelarut Terhadap Ekstraksi dari Kulit Buah Naga Merah (Hylocereus polyrhizus). 
Kovalen, 5(3), 271-279

Permadi, A., Sutanto, S., \& Wardatun, S. (2015). Perbandingan Metode Ekstraksi Bertingkat Dan Tidak Bertingkat Terhadap Flavonoid Total Herba Ciplukan Secara Kolorimetri. Jurnal Online Mahasiswa Bidang Farmasi, 1(1), 1-10.

Putra, B., Azizah, R., \& Clara, A. (2019). Potensi Ekstrak Etanol Daun Kelor ( Moringa oleifera L .) dalam Menurunkan Kadar Asam Urat Tikus Putih. Ad'-Dawaa'J.Pharm.Sci., 2(2), 63-69.

Rakanita, Y., Hastuti, L., Tandi, J., \& Mulyani, S. (2017). Efektivitas Antihiperurisemia Ekstrak Etanol Daun Seledri pada Tikus Induksi Kalium Oksonat. Journal of Tropical Pharmacy and Chemistry, 4(1), 1-6.

Rakholiya, K., \& Chanda, S. (2012). Pharmacognostic, Physicochemical and Phytochemical Investigation of Mangifera indica L. var. Kesar leaf. Asian Pacific Journal of Tropical Biomedicine, 2(2, Supplement), S680S684.

Rukmana, B., Choesrina, R., \& Fitrianginsih, S. (2017). Uji Aktivitas Antihiperurisemia Ekstrak Etanol Daun Jombang ( Sonchus oleraceus L
.) pada Tikus Wistar Jantan ( Rattus norvegicus ) yang Diinduksi Kalium Oksonat dengan Metode Kolorimetri Enzimatik. In Prosiding Farmasi (pp. 472-480). Bandung: FMIPA UNISBA. Suwandi, D., \& Perdana, F. (2018). Akyivitas Antihiperurisemia Ekstrak Etanol dan Fraksi-Fraksi Daun Jambu (Syzigium jambos L.) pada Mencit Jantan Galur Swiss Webster. Jurnal Ilmiah Farmako Bahari, 9(1), 35-44. Umboh, D., Queljoe, E., \& Yamlean, P. (2019). Uji Aktivitas Antihiperurisemia Ekstrak Etanol Daun Gedi Hijau (Abelmoschus manihot (L.) Medik) Pada Tikus Jantan Putih Galur Wistar (Rattus norvegicus). Jurnal Ilmu Farmasi, 8(4), 140-148.

Wahyuningsih, S., Yulinah, E., Sukrasno, \& Karina, N. (2015). Efek Antihiperurikemia Ekstrak Air Kelopak Bunga Rosela (Hibiscus sabdariffa L.) pada Tikus Putih Wistar Jantan. Jurnal Farmasi Sains Dan Terapan, 2(1), 4-7. 